\title{
Analisis Dampak Kepercayaan Terhadap Keputusan Pembelian Online: Perspektif Marketing MIX
}

\author{
Siti Muslimah \\ Universitas Muhammadiyah Palopo \\ sitimuslimahafid@gmail.com \\ Rahmad Solling Hamid \\ Universitas Muhammadiyah Palopo \\ rahmadshamid@umpalopo.ac.id

\section{Muhammad Aqsa \\ Universitas Muhammadiyah Palopo \\ muhammadaqsa@umpalopo.ac.id}

\begin{abstract}
Abstrak Perkembangan teknologi informasi telah membawa dampak positif dalam dunia bisnis dan pemasaran. Hadirnya platform digital marketing dapat memberikan keuntungan baik bagi pemasar maupun bagi konsumen. Tujuan penelitian bertujuan untuk mengetahui dampak kualitas produk, promosi, harga, tempat, dan kepercayaan terhadap keputusan pembelian online. Populasi dalam penelitian ini yaitu Mahasiswa Fakultas Ekonomi Dan Bisnis Universitas Muhammadiyah Palopo berjumlah 402 Mahasiswa. Penentuan jumlah sampel yaitu menggunakan rumus Slovin pada tingkat presisi 5\% diperoleh sebanyak 200 sampel. Metode analisis yang digunakan yaitu analisis regresi linier berganda. Hasil penelitian diperoleh informasi bahwa kualitas produk, harga, tempat, dan kepercayaan berpengaruh positif tidak signifikan terhadap keputusan pembelian onlien, sedangkan promosi memiliki dampak positif signifikan pada keputusan pembelian online.

Kata Kunci Kualitas Produk, Promosi, Harga, Tempat, Kepercayaan dan Keputusan Pembelian Onile.
\end{abstract}

\section{PENDAHULUAN}

Perkembangan teknologi informasi internet telah berdampak positif pada perkembangan dunia bisnis dan pemasaran. Aktivitas pemasaran dengan memanfaatkan teknologi internet saat ini telah banyak digunakan oleh pelaku bisnis dalam melakukan transaksi jual beli. Dengan adanya transaksi jual beli yang dilakukan secara online, kini terasa tidak ada jarak antara penjual dan pembeli, cukup dengan mengakses situs online melalui gadget pembeli dan penjual dapat terhubung secara langsung melalui dunia virtual. Mengingat jumlah pengguna internet yang terus meningkat dapat menjadi sebuah pasar yang potensial untuk dimanfatkan oleh pelaku usaha dalam memasarkan produk dan jasa.

Hal ini menunjukkan bahwa era pemanfaatan teknologi informasi sudah mulai dianggap tepat. Aktivitas pemasaran online telah mengubah perilaku konsumen dimana mereka dapat dengan mudah mencari informasi tentang produk yang ditawarkan. 
Dengan adanya layanan e-commerce, maka konsumen akan dimudahkan dalam melakukan transaksi pembelian secara cepat (Elondri, 2017).

Transaksi perdagangan telah mengikuti trend perkembangan teknologi dengan menggunakan jaringan internet. Pemanfaatan media online berbasis internet untuk berbagai inovasi dalam kegiatan jual beli menjadi pilihan perusahaan untuk mempromosikan produk kepada konsumen. Berganti fungsi internet yang dulunya hanya sebagai tempat mencari informasi kini menjadi tempat bertransaksi, selain itu internet juga menjadi kebutuhan utama masyarakat Indonesia saat ini.

Online shoping atau belanja online merupakan sebuah sarana berupa toko dengan tujuan untuk menawarkan produk barang maupun jasa melalui media internet yang memungkinakan konsumen atau pengunjung dapat melihat dan melakukan transaksi di toko online. Sejak kehadiran internet, para pelaku bisnis telah berusaha membuat toko online dan menjual produk kepada mereka yang sering menjelajahi dunia maya (internet). Para pelanggan dapat mengunjungi tokoh online (online shop) dengan mudah dan nyaman. Mereka dapat melakukan transaksi dimana saja dan kapan saja hanya dengan mengakses jaringan internet. Internet telah berdampak dan membawa perubahan salah satunya pada bidang pemasaran. Saat ini produsen dan konsumen dapat bertemu serta bertransaksi langsung melalui media pemasaran online. Selain menghadirkan kemudahan, aktivitas pemasaran melalui media online juga tidak memerlukan tempat dan terikat oleh waktu karena semua orang dapat bertransaksi secara bebas dalam internet (Nisa, 2018).

Memasarkan suatu produk melalui media internet seperti website dan media sosial (Instagram, Facebook, Whatsapp dan lain sebagainya) sama seperti strategi pemasaran secara tradisional. Diantaranya meliputi penciptaan nilai pelanggan dan merebut nilai pelanggan serta mempertahankan nilai pelanggan. Namun, strategi pemasaran menggunakan web dan media sosial dapat mengubah konsep marketing mix yang ada sebelumnya. Hal ini karena sebuah web dan sosial media dapat mempengaruhi perkembangan dan keputusan dalam strategi pemasaran terutama marketing mix (Nisa, 2018)

Beberapa hasil penelitian terdahulu yang mengkaji tentang pengaruh kualitas produk promosi harga dan kepercayaan terhadap keputusan pembelian secara online secara umum masih menghasilkan temuan yang berbeda atau adanya gap hasil penelitian. Penelitian yang di lakukan oleh Putra, Arifin, \& Sunarti (2017); Dewi, Hasiolan, \& Minarsih (2016), yang meneliti tentang pengaruh kualitas produk terhadap keputusan pembelian secara online memiliki hasil bahwa kualitas produk berpengaruh positif terhadap keputusan pembelian. Menurut Napian (2013), yang meneliti tentang kepercayaan berpengaruh postif terhadap keputusan pembelian sedangkan menurut Cherstiawan (2019), meneliti tentang kepercayaan tidak berpengaruh signifikan terhadap keputusan pembelian.

Dari latar belakang dan adanya gap yang sudah diuraikan diatas, maka tujuan penelitian ini yaitu untuk mengetahui dampak dari kualitas produk, promosi, harga, tempat, dan kepercayaan dan Keputusan Pembelian Online.

\section{LANDASAN TEORI}

\section{Kualitas Produk}

Kualitas adalah keseluruhan ciri atau karakteristik produk atau jasa dalam tujuannya untuk memenuhi kebutuhan dan harapan pelanggan (Sunardi \& Suprianto, 
2020). Kualitas produk memiliki tujuan bahwa barang hasil produksi dapat mencapai standar yang telah ditetapkan, agar biaya inspeksi seminimal mungkin, sehingga biaya desain produksi sekecil mungkin, serta biaya produksi menjadi serendah mungkin (Kotler \& Keller, 2015). Terdapat beberapa faktor yang mempengaruhi kualitas produk diantaranya yaitu yaitu:

1) Pasar (Market)

2) Uang (Money)

3) Manajemen (Management)

4) Manusia (Men)

5) Motivasi (Motivation)

6) Bahan (Material)

7) Mesin dan Mekanise (Machine and Mecanization)

8) Metode Informasi Modern (Modern Information Method)

9) Persyaratan Proses Produksi (Mounting Product Requirement)

\section{Promosi}

Menurut Kotler \& Amstrong (2016), mengumukakan pengertian promosi adalah suatu yang digunakan untuk memberitahukan dan membujuk pasar tentang produk atau jasa yang baru pada perusahaan melalui iklan, penjualan pribadi, promosi penjualan, maupun publikasi. Promosi merupakan salah satu proses komunikasi pemasaran yang dijalankan untuk dapat memberikan sebuah informasi secara luas, memberi pengaruh, serta mengingatkan sebuah target pasar kepada perusahaan dan prosuk supaya mau menerima, dan melakukan pembelian secara loyal terhadap barang dan jasa yang ditawarkan oleh perusahaan (Tjiptono \& Chandra, 2016). Beberapa jenis promosi yang berkembang saat ini yaitu:

1) Promosi secara fisik

Promosi seperti ini dijumpai pada event tertentu, seperti konser musik, bazaar, pameran. Dalam promosi ini biasanya penjual menyediakan booth untuk menampilkan dan mempromosikan produk yang ditawarkan kepada konsumen.

2) Promosi dengan menggunakan media Tradisional

Promosi semacam ini sangat efektif dalam meningkatkan penjualan. Beberapa diantaranya dipromosikan melalui media cetak seperti majalah, tabloid, koran, radio, telivisi, spanduk, dan baliho.

3) Promosi dengan menggunakan media digital

Perkembangan teknologi dan media informasi telah mengubah cara berpromosi di era digital. Sebagian besar kegiatan promosi yang dilakukan melalui media digital dilakukan melalui media sosial, jaringan website, dan mesin pencari.

\section{Harga}

Menurut Kurniawan (2018), harga merupakan salah satu penentu keberhasilan suatu perusahaan karena harga merupakan indikator penentu seberapa besar keuntungan yang akan diperoleh oleh suatu perusahaan setelah produk tersebut terjual kepada konsumen. Kemajuan teknologi akan mengakibatkan persaingan yang sangat ketat untuk memperoleh dan mempertahankan pelanggan. Perusahaan harus melakukan penetapan harga yang bersaing agar mampu bertahan dan tetap mendapatkan pelanggan. Harga adalah suatu sistem manajemen perusahaan yang dapat menentukan harga dasar yang dianggap tepat pada suatu produk maupun jasa serta menentukan strategi berupa 
potongan harga, biaya angkut dan beberapa variabel yang bersangkutan (Kotler \& Amstrong, 2016).

\section{Tempat}

Tempat atau saluran distribusi merupakan elemen penting dalam mendukung optimalisasi pemasaran produk suatu perusahaan. Aktivitas pemasaran online salah satunya dilakukan pada platform media digital. Pemasar tentunya harus mampu membangun opini dan kepercayaan kepada konsumen atas produk atau jasa yang dipasarkan melalui media pemasaran online. Menurut Kotler \& Amstrong (2016), tempat atau saluran distribusi merupakan seperangkat organisasi yang paling bergantung satu sama lain, yang dilibatkan dalam proses penyediaan produk atau jasa, untuk digunakan oleh konsumen. Kualitas informasi, kualitas sistem, kualitas layanan pada media pemasaran online (ecommerce) dapat dipercaya sebagai media pemasaran produk yang efektif (Hamid \& Ikbal, 2017). Tempat bukan berarti hanya lokasi perusahaan saja tapi juga termasuk di dalamnya saluran pemasaran, kumpulan dan pengaturan lokasi, persediaan serta transportasi. Dalam industri jasa, tempat terutama mengacu pada lokasi dan distribusi yang dapat memberikan kemudahan bagi pelanggan dalam memperoleh jasa perusahaan. Keputusan-keputusan lokasi dan penjualan meliputi pertimbangan mengenai cara penyampaian produk kepada pelanggan dan di mana produk harus ditempatkan. Dalam menentukan place atau saluran distribusi, perusahaan harus mengutamakan tempattempat yang sesuai dengan target market. Sehingga pada intinya, dalam menentukan marketing mix harus didasari pada prinsip-prinsip keadilan dan kejujuran. Fungsi distribusi bertujuan untuk mempercepat sampainya barang di tangan konsumen atau pasar pada saat yang tepat.

\section{Kepercayaan}

Kepercayaan (trust) adalah komponen sentral dalam melakukan pembelian melalui media online. Hanya pelanggan yang memiliki kepercayaan yang berani melakukan trnasaksi pembelian melalui media internet. Kualitas informasi yang tersedia pada platform media pemasaran online (e-commerce) dapat dipercaya (Hamid \& Ikbal, 2017). Tanpa adanya kepercayaan (trust) mustahil orang mau melakukan pembelian online. Jadi tidak mudah untuk membentuk trust (kepercayaan) di benak konsumen karena kepecayaan berhubungan dengan sikap seseorang. Kepercayaan yang tinggi dari konsumen akan membangun minat beli konsumen yang berdampak pada loyalitas konsumen (Istanti, 2017). Kepercayaan sangatlah mempengaruhi konsumen dalam menentukan minat beli ulang kedepannya karena kepercayaan konsumen adalah pondasi utama dari suatu bisnis, apalagi dalam berbelanja online. Transaksi bisnis akan terjadi bila antara kedua belah pihak yaitu pembeli dan penjual saling percaya. Maka dari itu kepercayaan menjadi suatu hal yang penting yang dapat membengaruhi minat beli ulang konsumen kedepannya.

Pengertian kepercayaan tersebut memiliki beberapa hal penting yang di antaranya yaitu konsumen yang memiliki kepercayaan akan tersedia untuk bergantung pada penyedia jasa dan juga bersedia untuk melakukan tindakan untuk penyedia jasa. Kepercayaan memiliki tiga aspek dari karateristik penyedia jasa yaitu ability, integrity, motivation. Pertama-tama konsumen akan menilai apakah provider cukup kopeten untuk menjalankan kewajiban dan melayani konsumen. Kedua konsumen akan menilai apakah perusahaan memiliki integritas, dimana konsumen dapat percaya pada pekerjaan 
perusahaan. Terahir konsumen mempercayai bahwa penyedia jasa memiliki motivasi untuk tidak melakukan tindakan yang tidak sesuai dengan harapan konsumen.

\section{Keputusan Pembelian}

Pengambilan keputusan yang dilakukan merupakan salah satu pendekatan seseorang untuk melakukan pemberian barang atau jasa yang akan digunakan untuk mendapatkan kualitas produk yang baik (Sari, Arifin, \& Hufron, 2020). Keputusan pembelian menurut Kotler \& Amstrong (2016) yaitu suatu tindakan pembelian pada brand yang paling disukai, dimana dua elemen bisa berada antara niat pembelian dan keputusan pembelian. Keputusan pembelian merupakan suatu tahapan proses konsumen dalam melakukan pembelian produk atau jasa yang diinginkan (Istanti, 2017). Keputusan pembelian menurut. Dari definisi diatas, maka dapat disimpulkan bahwa proses keputusan pembelian adalah proses yang dilakukan oleh konsumen untuk membeli suatu produk setelah memiliki informasi dan membandingkan dengan produk merek lainnya.

\section{METODOLOGI PENELITIAN}

Pendekatan penelitian yang digunakan yaitu pendekatan penelitian kuantitatif. Populasi merupakan keseluruhan dari objek atau subjek yang berada pada suatu wilayah serta telah memenuhi syarat yang ditetapkan yang berhubungan pada masalah penelitian, keseluruhan individu yang terdapat dalam ruang lingkup penelitian. kemudian ditarik kesimpulannya (Hamid \& Patra, 2019). Populasi pada penelitian ini yaitu mahasiswa Fakultas Ekonomi Dan Bisnis Universitas Muhammadiyah Palopo berjumlah 402. Sampel merupakan keseluruhan dari kelompok individu yang ditetapkan atau dipilih yang bersumber dari populasinya (Hamid \& Patra, 2019). Untuk menentukan besarnya sampel, peneliti menggunakan rumus slovin sebagai berikut:

$$
n=\frac{N}{N \cdot d^{2}+1}
$$

Ket:

n: jumlah sampel

$\mathrm{N}$ : jumlah populasi

$\mathrm{d}^{2}$ : presisi (ditetapakan 5\% dengan tingkatan kepercayaan 90\%)

Dari rumus slovin diatas, maka:

$$
\begin{aligned}
n & =\frac{402}{1+402 \cdot(0,05)^{2}} \\
& =200,49 \text { dibulatkan menjadi } 200
\end{aligned}
$$

Jadi, jumlah minimum responden adalah 200.

Penelitian ini melalui teknik pengujian data yaitu uji validitas, uji reliabilitas, dan uji hipotesis dengan pendekatan analsisi regresi linier berganda. Uji regresi linear berganda bertujuan untuk mengetahui arah hubungan antara variabel independen dengan variabel dependen apakah positif atau negatif. Adapun bentuk persamaan regresi adalah: $\mathrm{Y}=\mathrm{a}+\mathrm{b} 1 \mathrm{X} 1+\mathrm{b} 2 \mathrm{X} 2+\mathrm{b} 3 \mathrm{X} 3+\mathrm{b} 4 \mathrm{X} 4+\mathrm{b} 5 \mathrm{X} 5+\mathrm{e}$

Dimana:

$\mathrm{Y} \quad=$ Keputusan pembelian

a $\quad=$ Harga $\mathrm{Y}$ bila $\mathrm{X}=0$ (harga konstan) 


$$
\begin{array}{ll}
\mathrm{b} 1-\mathrm{b} 4 & =\text { Koefisien regresi } \\
\mathrm{X} 1 & =\text { Kualitas Produk } \\
\mathrm{X} 2 & =\text { Harga } \\
\mathrm{X} 3 & =\text { Promosi } \\
\mathrm{X} 4 & =\text { Tempat } \\
\mathrm{X} 5 & =\text { Kepercayaan } \\
\mathrm{e} & =\text { Standar } \text { error }
\end{array}
$$

\begin{tabular}{|c|c|c|c|}
\hline Variabel & Definisi operasional & Indikator & Sumber \\
\hline $\begin{array}{l}\text { Kualitas } \\
\text { produk }\end{array}$ & $\begin{array}{l}\text { kualitas produk } \\
\text { merupakan } \\
\text { kemampuan sebuah } \\
\text { produk dalam } \\
\text { memperagakan } \\
\text { fungsinya, hal ini } \\
\text { termasuk keseluruhan } \\
\text { daya tahan, keandalan, } \\
\text { ketepatan, kemudahan } \\
\text { pengoperasian, dan } \\
\text { reparasi produk, juga } \\
\text { atribut produk lainnya. }\end{array}$ & $\begin{array}{l}\text { 1. Features(fitur) } \\
\text { 2. Reability } \\
\text { (kehandalan) } \\
\text { 3. Comformance to } \\
\text { specification } \\
\text { (kesesuaian dengan } \\
\text { spesifikasi) } \\
\text { 4. Durability (daya } \\
\text { tahan) }\end{array}$ & $\begin{array}{l}\text { (Kotler \& } \\
\text { Amstrong, 2016); } \\
\text { (Arrosyid, 2018) }\end{array}$ \\
\hline Promosi & $\begin{array}{lr}\text { Promosi } & \text { adalah } \\
\text { kegiatan } & \text { yang } \\
\text { dilakukan perusahaan } \\
\text { untuk } \\
\text { mengkomunikasikan } \\
\text { manfaat produk dan } \\
\text { sebagai alat untuk } \\
\text { mempengaruhi } \\
\text { konsumen dalam } \\
\text { kegiatan pembelian } \\
\text { atau penggunaan jasa } \\
\text { sesuai dengan } \\
\text { kebutuhan. }\end{array}$ & $\begin{array}{l}\text { 1. Jangkauan promosi } \\
\text { 2. Kuantitas } \\
\text { penayangan iklan } \\
\text { 3. Kualitas } \\
\text { penyampaian pesan } \\
\text { dalam penayangan } \\
\text { iklan di media } \\
\text { sosial } \\
\text { 4. Periklanan }\end{array}$ & $\begin{array}{l}\text { (Lupiyoadi, 2013); } \\
\text { (Yusup, 2011) }\end{array}$ \\
\hline Harga & $\begin{array}{l}\text { Harga merupakan satu- } \\
\text { satunya elemen bauran } \\
\text { pemasaran yang } \\
\text { menghasilkan } \\
\text { pendapatan, elemen- } \\
\text { elemen lainnya } \\
\text { menimbulkan biaya. } \\
\text { Harga juga merupakan }\end{array}$ & $\begin{array}{l}\text { 1. Keterjangkauan } \\
\text { harga. } \\
\text { 2. Kesesuaian harga } \\
\text { dengan kualitas } \\
\text { produk } \\
\text { 3. Daya saing harga } \\
\text { 4. Kesesuaian harga } \\
\text { dengan manfaat }\end{array}$ & 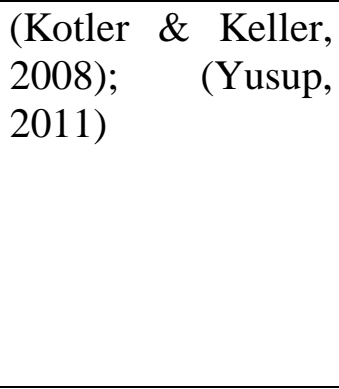 \\
\hline
\end{tabular}

Berikut disajikan defenisi dan indikator untuk setiap variabel yang digunakan pada penelitian ini.

Tabel 1

Defenisi dan Indikator Variabel Penelitian 


\begin{tabular}{|c|c|c|c|}
\hline & $\begin{array}{l}\text { salah satu elemen } \\
\text { bauran pemasaran } \\
\text { yang paling fleksibel, } \\
\text { harga dapat diubah } \\
\text { dengan cepat, tidak } \\
\text { seperti ciri khas } \\
\text { (feature) produk dan } \\
\text { perjanjian distribusi. }\end{array}$ & & \\
\hline $\begin{array}{l}\text { Tempat/ } \\
\text { distribusi }\end{array}$ & $\begin{array}{l}\text { Distribusi merupakan } \\
\text { program yang terdiri } \\
\text { atas berbagai kegiatan } \\
\text { pemasaran yang } \\
\text { berusaha mempelancar } \\
\text { dan mempermudah } \\
\text { penyampaian barang } \\
\text { dan jasa dari produsen } \\
\text { kepada konsumen, } \\
\text { sehingga sesuai } \\
\text { penggunaannya sesang di } \\
\text { dengan yang } \\
\text { harapkan. }\end{array}$ & $\begin{array}{l}\text { 1. Kemudahan } \\
\text { mendapatkan } \\
\text { produk } \\
\text { 2. Ketersedian produk } \\
\text { 3. Lama waktu } \\
\text { pengiriman } \\
\text { 4. Variasi alat } \\
\text { pengiriman }\end{array}$ & $\begin{array}{l}\text { (Kotler \& } \\
\text { Amstrong, 2016) }\end{array}$ \\
\hline Kepercayaan & $\begin{array}{l}\text { Kepercayaan adalah } \\
\text { semua pengetahuan } \\
\text { yang dimiliki } \\
\text { konsumen dan semua } \\
\text { kesimpulan yang } \\
\text { dibuat konsumen } \\
\text { tentang objek, atribut } \\
\text { dan manfaatnya. }\end{array}$ & $\begin{array}{l}\text { 1. Aman } \\
\text { 2. Dapat diandalkan } \\
\text { 3. Terpercaya } \\
\text { 4. Ketertarikan }\end{array}$ & $\begin{array}{l}\text { (Sunarto, 2006); } \\
\text { (Hsu, Chang, Chu, } \\
\text { \& Lee, 2014) }\end{array}$ \\
\hline $\begin{array}{l}\text { Keputusan } \\
\text { pembelian }\end{array}$ & $\begin{array}{lr}\text { keputusan pembelian } \\
\text { adalah proses dimana } \\
\text { merumuskan berbagai } \\
\text { alternatif tindakan } \\
\text { guna menjatuhkan } \\
\text { suatu pilihan pada } \\
\text { salah satu alternatif } \\
\text { tertentu } \\
\text { melakukan rantuk } \\
\text { pembelian. }\end{array}$ & $\begin{array}{l}\text { 1. Pemilihan terhadap } \\
\text { produk } \\
\text { 2. Mempunyai } \\
\text { manfaat } \\
\text { 3. Sesuai kebutuhan } \\
\text { 4. Perilaku setelah } \\
\text { pembelian }\end{array}$ & (Sumarwan, 2011) \\
\hline
\end{tabular}

\section{HASIL PENELITIAN}

\section{Gambara Umum Responden}

Berikut adalah gambaran umum dari responden yang digunakan didalam penelitian ini yaitu terdiri dari usia, jenis kelamin, tingkat pendidikan, pekerjaan, dan jumlah kunjungan. 


\section{a. Deskripsi Responden Berdasarkan Jenis Kelamin}

Berikut merupakan penyajian hasil uji deskripsi berdasarkan jenis kelamin.

Tabel 2. Deskripsi Responden Berdasarkan Jenis Kelamin

\begin{tabular}{|c|l|c|c|}
\hline No & Jenis Kelamin & Jumlah Responden & Persentase \\
\hline 1 & Laki-laki & 95 & 47,5 \\
\hline 2 & Perempuan & 105 & 52,5 \\
\hline \multicolumn{2}{|c|}{ Jumlah } & 200 & 200 \\
\hline
\end{tabular}

Tabel 2 diatas menunjukkan bahwa sebanyak 95 orang atau 47,5\% responden laki-laki dan sebanyak 105 orang atau 52,5\% responden perempuan.

\section{b. Deskripsi Responden Berdasarkan Frekuensi Pembelian}

Berikut penyajian hasil uji deskripsi berdasarkan frekuensi pembelian.

Tabel 3. Deskripsi Responden Berdasarkan Frekuensi Pembelian

\begin{tabular}{|c|c|c|c|}
\hline No & $\begin{array}{c}\text { Frekuensi } \\
\text { Pembelian (Dalam } \\
\text { Sebulan) }\end{array}$ & Jumlah Responden & Persentase \\
\hline 1 & 1 Kali & 95 & 47,50 \\
\hline 2 & 2 Kali & 85 & 42,50 \\
\hline 3 & $<2$ Kali & 20 & 10,00 \\
\hline \multicolumn{2}{|c|}{ Jumlah } & 200 & 100 \\
\hline
\end{tabular}

Tabel 3 menunjukkan bahwa sebanyak 95 orang atau 47,50\% responden dengan frekuensi pembelian sekali, selanjutnya sebanyak 85 orang atau $42,50 \%$ dengan frekuensi pembelian dua kali. Selanjutnya sebanyak 20 orang atau 10,00\% dengan frekuensi pembelian lebih dari dua kali.

\section{c. Deskripsi Responden Berdasarkan Jurusan/Program Studi}

Berikut merupakan hasil uji deskripsi berdasarkan pekerjaan.

Tabel 4. Deskripsi Responden Berdasarkan Jurusan/Program Studi

\begin{tabular}{|c|c|c|c|}
\hline No & Jurusan/ Program Studi & Jumlah Responden & Persentase \\
\hline 1 & Manajemen & 99 & 45,00 \\
\hline 2 & Akuntansi & 49 & 34,00 \\
\hline 3 & Ekonomi Pembangunan & 52 & 21,00 \\
\hline & Jumlah & 200 & 100 \\
\hline
\end{tabular}

Tabel 4 menunjukkan bahwa sebanyak 99 atau 45,00\% orang responden mahasiswa berasal dari jurusan manajemen. Selanjutnya, sebanyak 49 atau 34,00\% orang responden mahasiswa berasal dari jurusan akuntansi, dan sebanyak 52 orang atau $21,00 \%$ responden berasal dari jurusan ekonomi pembangunan. 


\section{Uji validitas dan reliabilitas}

Adapun hasil pengujian validitas dan reliabilitas untuk variabel yang digunakan dalam penelitian ini yaitu sebagai berikut:

Tabel 5. Hasil Uji Validitas dan Reliabilitas

\begin{tabular}{|c|c|c|c|c|c|c|}
\hline Variabel & Item & $\mathbf{r}_{\text {hitung }}$ & $\mathbf{r}_{\text {tabel }}$ & Alpha & \multicolumn{2}{|c|}{ Keterangan } \\
\hline Kualitas & $\begin{array}{l}\mathrm{X} 1.1 \\
\mathrm{X} 1.2 \\
\mathrm{X} 1.3 \\
\mathrm{X} 1.4\end{array}$ & $\begin{array}{l}0,674 \\
0,797 \\
0,757 \\
0,616\end{array}$ & $\begin{array}{l}0.1161 \\
0.1161 \\
0.1161 \\
0.1161\end{array}$ & 0,789 & $\begin{array}{l}\text { Valid } \\
\text { Valid } \\
\text { Valid } \\
\text { Valid }\end{array}$ & Reliabel \\
\hline Promosi & $\begin{array}{l}X 2.1 \\
\text { X2.2 } \\
\text { X2.3 } \\
\text { X2.4 } \\
\end{array}$ & $\begin{array}{l}0,670 \\
0,771 \\
0,714 \\
0,630 \\
\end{array}$ & $\begin{array}{l}0.1161 \\
0.1161 \\
0.1161 \\
0.1161\end{array}$ & 0,777 & $\begin{array}{c}\text { Valid } \\
\text { Valid } \\
\text { Valid } \\
\text { Valid }\end{array}$ & Reliabel \\
\hline Harga & $\begin{array}{l}\text { X3.1 } \\
\text { X3.2 } \\
\text { X3.3 } \\
\text { X3.4 }\end{array}$ & $\begin{array}{l}0,597 \\
0,753 \\
0,783 \\
0,608 \\
\end{array}$ & $\begin{array}{l}0.1161 \\
0.1161 \\
0.1161 \\
0.1161\end{array}$ & 0,762 & $\begin{array}{c}\text { Valid } \\
\text { Valid } \\
\text { Valid } \\
\text { Valid }\end{array}$ & Reliabel \\
\hline Tempat & $\begin{array}{l}\text { X4.1 } \\
\text { X4.2 } \\
\text { X4.3 } \\
\text { X4.4 }\end{array}$ & $\begin{array}{l}0,612 \\
0,790 \\
0,726 \\
0,609\end{array}$ & $\begin{array}{l}0.1161 \\
0.1161 \\
0.1161 \\
0.1161\end{array}$ & 0,764 & $\begin{array}{l}\text { Valid } \\
\text { Valid } \\
\text { Valid } \\
\text { Valid }\end{array}$ & Reliabel \\
\hline Kepercayaan & $\begin{array}{l}\text { X5.1 } \\
X 5.2 \\
X 5.3 \\
X 5.4\end{array}$ & $\begin{array}{l}0,673 \\
0,736 \\
0,699 \\
0,415\end{array}$ & $\begin{array}{l}0.1161 \\
0.1161 \\
0.1161 \\
0.1161\end{array}$ & 0,667 & $\begin{array}{l}\text { Valid } \\
\text { Valid } \\
\text { Valid } \\
\text { Valid }\end{array}$ & Reliabel \\
\hline $\begin{array}{l}\text { Keputusan } \\
\text { pembelian }\end{array}$ & $\begin{array}{l}\text { Y1 } \\
\text { Y2 } \\
\text { Y2 } \\
\text { Y4 }\end{array}$ & $\begin{array}{c}0,612 \\
0,769 \\
0,686 \\
0,650\end{array}$ & $\begin{array}{l}0.1161 \\
0.1161 \\
0.1161 \\
0.1161\end{array}$ & 0,637 & $\begin{array}{l}\text { Valid } \\
\text { Valid } \\
\text { Valid } \\
\text { Valid }\end{array}$ & Reliabel \\
\hline
\end{tabular}

Berdasarkan Tabel diatas semua item pernyataan untuk variabel kualitas, promosi, harga, tempat, kepercayaan, dan keputusan pembelian dinyatakan valid karena $r$ hitung $>r$ tabel 0,1161 . Untuk hasil uji reliabilitas variabel kualitas, promosi, harga, tempat, kepercayaan, dan keputusan pembelian dapat disimpulkan bahwa semua item pernyataan reliabel karena nilai dari cronbach's alpha keseluruhan variabel >0,60.

\section{Uji hipotesis} berikut:

Adapun hasil perhitungan regresi linear berganda dapat tersaji pada tabel 6 sebagai 
Tabel 6. Regresi Linear Berganda

\section{Coefficients $^{\mathrm{a}}$}

\begin{tabular}{|l|r|r|r|r|r|}
\hline Model & \multicolumn{2}{|c|}{$\begin{array}{c}\text { Unstandardized } \\
\text { Coefficients }\end{array}$} & $\begin{array}{c}\text { Standardized } \\
\text { Coefficients }\end{array}$ & \multicolumn{1}{c|}{ Sig. } \\
\cline { 2 - 4 } & \multicolumn{1}{|c|}{$\mathrm{B}$} & Std. Error & \multicolumn{1}{c|}{ Beta } & & \\
\hline (Constant) & 6.019 & 4.574 & & 1.316 & .198 \\
kualitas & -.003 & .128 & -.004 & -.025 & .980 \\
produk & & & & & \\
promosi & .343 & .140 & .402 & 2.450 & .020 \\
Harga & -.033 & .192 & -.029 & -.170 & .866 \\
Tempat & .073 & .126 & .100 & .583 & .564 \\
kepercayaan & .120 & .152 & .134 & .791 & .435 \\
\hline
\end{tabular}

\section{Secara parsial (uji t)}

Pengaruh kualitas produk terhadap keputusan pembelian berpengaruh positif tidak signifikan dengan nilai probabilitas sebesar 0,980 lebih besar dari level of significance ( $\alpha$ $=0,05)$. Selanjutnya pengaruh promosi terhadap keputusan pembelian berpengaruh positif signifikan dengan nilai probabilitas sebesar 0,020 lebih kecil dari level of significance $(\alpha=0,05)$. Untuk pengaruh harga terhadap keputusan pembelian berpengaruh positif tidak signifikan dengan nilai probabilitas sebesar 0,866 lebih besar dari level of significance $(\alpha=0,05)$. Selanjutnya, untuk pengaruh tempat terhadap keputusan pembelian berpengaruh positif tidak signifikan dengan nilai probabilitas sebesar 0,564 lebih besar dari level of significance $(\alpha=0,05)$. Sedangakan untuk pengaruh kepercayaan terhadap keputusan pembelian berpengaruh positif tidak signifikan dengan probabilitas sebesar 0,435 lebih besar dari level of signifikan $(\alpha=0,05)$.

\section{Koefisien determinasi $\left(\mathbf{R}^{2}\right)$}

Uji koefisien determinasi ini digunakan untuk mengukur seberapa jauhvariabelvariabel bebas dalam menerangkan variabel terikatnya. Nilai koefisien determinasi untuk dua variabel bebas ditentukan dengan nilai:

Tabel 8

Hasil Koefisien Determinasi $\left(\mathbf{R}^{2}\right)$

\begin{tabular}{|r|r|r|r|}
\hline \multicolumn{1}{|c|}{$\mathrm{R}$} & R Square & Adjusted R Square & $\begin{array}{c}\text { Std. Error of the } \\
\text { Estimate }\end{array}$ \\
\hline $.451^{\mathrm{a}}$ & .204 & .075 & 2.063 \\
\hline
\end{tabular}

Berdasakan Tabel 8 hasil koefisien determinasi $\left(\mathrm{R}^{2}\right)$ diatas, diperoleh nilai adjusted $R$ square sebesar 0,075. Artinya besaran variasi perubahan keputusan pembelian online pada mahasiswa Universitas Muhammadiyah Palopo dapat dipengaruhi oleh variabel kualitas produk, promosi, harga, tempat, dan kepercayaan sebesar 7,5\%. Sedangkan sisanya sebesar $92,5 \%$ dipengaruhi oleh variabel lain yang tidak di terdapat dalam model penelitian ini. 


\section{Pembahasan}

\section{Pengaruh Kualitas Produk terhadap Keputusan Pembelian Online}

Dari hasil analisis koefisien regresi kualitas produk menunjukan angka sebesar 0.003 artinya setiap peningkatan kualitas produk sebesar $1 \%$ akan meningkatkan keputusan pembelian sebesar $0.003 \%$. berdasarkan uji t diperolah hasil bahwa t hitung -.025 lebih kecil dari t tabel 1,652 dengan nilai signifikan sebesar 0,980 lebih besar dari 0,05. Karena t hitung lebih kecil dari t tabel maka hal ini menunjukkan bahwa H1 ditolak, artinya kualitas produk tidak berpengaruh terhadap keputusan pembelian. Berdasarkan hasil penelitian (Putra et al., 2017) variabel kualitas produk berpengaruh secara signifikan terhadap keputusan pembelian tidak sejalan dengan hasil penelitian, Penelitian ini memiliki hasil bahwa kualitas produk berpengaruh terhadap keputusan pembelian.

\section{Pengaruh Promosi terhadap Keputusan Pembelian Online}

Dari hasil analisis koefisien regresi promosi menunjukan angka sebesar 0.343 artinya setiap peningkatan promosi sebesar $1 \%$ akan meningkatkan keputusan pembelian sebesar $0.343 \%$. berdasarkan uji t diperolah hasil bahwa t hitung 2.450 lebih besar dari t tabel 1,652 dengan nilai signifikan sebesar 0,020 lebih kecil dari 0,05. Karena t hitung lebih besar dari t tabel maka hal ini menunjukkan bahwa $\mathrm{H} 2$ diterima, artinya promosi berpengaruh terhadap keputusan pembelian. Berdasarkan hasil penelitian (Napian, 2013) variabel promosi berpengaruh secara signifikan terhadap keputusan pembelian sejalan dengan hasil penelitian, penelitian ini memilki hasil bahwa promosi berpengaruh signifikan terhadap keputusan pembelian.

\section{Pengaruh Harga terhadap Keputusan Pembelian Online}

Dari hasil analisis koefisien regresi harga menunjukan angka sebesar 0.033 artinya setiap peningkatan harga sebesar $1 \%$ akan meningkatkan keputusan pembelian sebesar $0.033 \%$. berdasarkan uji t diperolah hasil bahwa thitung -.170 lebih kecil dari t tabel 1,652 dengan nilai signifikan sebesar 0,866 lebih besar dari 0,05. Karena t hitung lebih kecil dari t tabel maka hal ini menunjukkan bahwa $\mathrm{H} 3$ ditolak, artinya harga tidak berpengaruh terhadap keputusan pembelian. Berdasarkan hasil penelitian (Sitompul \& Mastono, 2017) variabel harga tidak berpengaruh secara signifikan terhadap keputusan pembelian sejalan dengan hasil penelitian, penelitian ini memiliki bahwa harga tidak berpengaruh terhadap keputusan pembelian.

\section{Pengaruh tempat terhadap Keputusan Pembelian Online}

Dari hasil analisis koefisien regresi tempat menunjukan angka sebesar 0.073 artinya setiap peningkatan tempat sebesar $1 \%$ akan meningkatkan keputusan pembelian sebesar $0.073 \%$. berdasarkan uji t diperolah hasil bahwa t hitung 0.583 lebih kecil dari t tabel 1,652 dengan nilai signifikan sebesar 0,564 lebih besar dari 0,05. Karena t hitung lebih kecil dari t tabel maka hal ini menunjukkan bahwa $\mathrm{H} 4$ ditolak, artinya tempat tidak berpengaruh terhadap keputusan pembelian. Berdasarkan hasil penelitian (Dewi et al., 2016) variabel tempat tidak berpengaruh secara signifikan terhadap keputusan pembelian sejalan dengan hasil penelitian. Penelitian ini memiliki bahwa tempat tidak berpengaruh terhadap keputusan pembelian.

\section{Pengaruh kepercayaan terhadap Keputusan Pembelian Online}

Dari hasil analisis koefisien regresi kepercayaan menunjukan angka sebesar 0.0 artinya setiap peningkatan kepercayaan sebesar $1 \%$ akan meningkatkan keputusan pembelian sebesar $0.073 \%$. berdasarkan uji $t$ diperolah hasil bahwa t hitung 0.791 lebih kecil dari $t$ tabel 1,652 dengan nilai signifikan sebesar 0,435 lebih besar dari 0,05. Karena t hitung lebih kecil dari t tabel maka hal ini menunjukkan bahwa H5 ditolak, artinya harga tidak 
berpengaruh terhadap keputusan pembelian. Berdasarkan hasil penelitian (Sitompul \& Mastono, 2017) variabel harga tidak berpengaruh secara signifikan terhadap keputusan pembelian sejalan dengan hasil penelitian.

\section{KESIMPULAN}

Berdasarkan hasil analisis statistik yang telah diuraikan sebelumnya dapat diambil beberapa kesimpulan diantaranya yaitu kualitas produk tidak berpengaruh signifikan terhadap keputusan pembelian. Berdasarkan hasil analisis bahwa untuk variabel kualitas produk, harga, tempat, dan kepercayaan tidak berpengaruh terhadap keputusan pembelian. Sedangkan untuk variabel promosi berpengaruh signifikan terhadap keputusan pembelian secara online. Dengan demikian, dapat diartikan bahwa kualitas produk, harga, tempat dan kepercayaan masih dipersepsikan kurang baik oleh responden dalam memutuskan untuk melakukan pembelian secara online. Informasi pada temuan penelitian ini dapat menambah informasi pengetahuan bagi pelapak atau penjual dalam mempelajari pola perilaku konsumen kelompok muda atau milenial dalam hal aktivitas pemasaran online. Hendaknya penelitian selanjutnya fokus pada salah satu media pemasaran online seperti Lazada, Shopee, dan Tokopedia). Selanjutnya, penelitian ini memiliki keterbatasan diantaranya yaitu pertama, penggunaan sampel penelitian hanya berfokus pada responden mahasiswa satu lingkup perguruan tinggi. Kedua, penelitian ini tidak difokuskan pada salah satu media pemasaran online.

\section{DAFTAR PUSTAKA}

Arrosyid, M. I. (2018). Analisis Pengaruh Promnosi Kepuasan Pelanggan Dan Kualitas Produk Dan Pembelian Ulang Terhadap Aplikasi Belanja Online Di Lazada (Studi Kasus Di Surakarta). Retrieved from http://eprints.ums.ac.id/63515/13/NASKAH PUBLIKASI anyar dewe123.pdf

Cherstiawan, A. (2019). Pengaruh Kepercayaan, Persepsi Harga, dan Promosi Dalam Keputusan Pembelian di Tokopedia pada Mahasiswa Universitas Kristen Krida Wacana. Ilmiah Manajemen Bisnis, 19(2), 1-18.

Dewi, W. S., Hasiolan, L. B., \& Minarsih, M. M. (2016). Pengaruh kualitas produk, kepercayaan terhadap keputusan pembelian dengan kepuasan konsumen sebagai variabel intervening Studi kasus pada Susu Bebelac di Giant Hypermarket Karangayu Semarang. Jurnal of Management, 2(2), 1-19.

Elondri, E. (2017). Pengaruh Kemudahan, Promosi Dan Kepuasan Transaksi Onlineshopping Terhadap Keputusan Pembelian Online (Survey Pada Konsumen Shopee. co. id). Jurnal Apresiasi Ekonomi, 5(3), 155-160.

Hamid, R. S., \& Ikbal, M. (2017). Analisis Dampak Kepercayaan pada Penggunaan Media Pemasaran Online ( E-Commerce ) yang Diadopsi oleh UMKM $\square$ : Perspektif Model DeLone \& McLean. Jurnal Manajemen Teknologi, 16(3), 310-337.

Hamid, R. S., \& Patra, I. K. (2019). PENGANTAR STATISTIKA UNTUK RISET BISNIS DAN EKONOMI Konsep Dasar dan Aplikasi SPSS versi 25. Banten: CV. AA. RIZKY.

Hsu, M. H., Chang, C. M., Chu, K. K., \& Lee, Y. J. (2014). Determinants of repurchase intention in online group-buying: The perspectives of DeLone \& McLean is success 
model and trust. Computers in Human Behavior, 36, 234-245. https://doi.org/10.1016/j.chb.2014.03.065

Istanti. (2017). Pengaruh Harga, Kepercayaan, Kemudahan Berbelanja dan E-promosi Terhadap Keputusan Pembelian Belanja Online di Kota Surabaya. Jurnal Bisnis \& Teknologi Politeknik, 4(1), 14-22.

Kotler, P., \& Amstrong, G. (2016). Dasar-dasar Pemasaran. Jilid 1, Edisi Kesembilan. Jakarta: Erlangga.

Kotler, P., \& Keller, K. L. (2008). Manajemen Pemasaran (Edisi Kedua Belas), Cetakan Ketiga. Jakarta: PT. Indeks.

Kotler, P., \& Keller, K. L. (2015). Marketing management, global edition. Pearson Education Limited Edinburgh Gate, England.

Kurniawan, A. R. (2018). Dasar-Dasar Marketing. Penerbit Quadrant, Yogyakarta.

Lupiyoadi, R. (2013). Manajemen Pemasaran Jasa (Edisi Ketiga). Jakarta: Salemba Empat.

Napian, S. (2013). Analisis Pengaruh Kualitas Produk, Promosi, Kepercayaan Merek, Dan Kepuasan Konsumen Terhadap Keputusan Pembelian Sepeda Motor Yamaha Mio Soul. (Studi Pada Pengguna Yamaha Mio Soul Di Wilayah Ciputat) (universitas islam negeri). Retrieved from http://repository.uinjkt.ac.id/dspace/bitstream/123456789/23781/1/skripsi pdf.pdf

Nisa, A. sholihatun. (2018). Analisis Pengaruh Harga Kepercayaan Dan Kualitas Pelayanan Terhadap Minat Beli Ulang Dalam Berbelanja Online Di Instagram (Studi Empiris Pada Mahasiswa Universitas Muhammadiyah Surakarta). Retrieved from http://eprints.ums.ac.id/62047/12/naskah publikasi-248 athiyah.pdf

Putra, G. permadi, Arifin, Z., \& Sunarti. (2017). Pengaruh Kualitas Produk Terhadap Keputusan Pembelian Dan Dampaknya Terhadap Kepuasan Konsumen (Survei Pada Mahasiswa Administrasi Bisnis Fakultas Ilmu Administrasi Angkatan 2013 Dan 2014 Universitas Brawijaya Yang Melakukan Pembelian Paket Data Kampus). Jurnal Administrasi Bisnis, 48(1), 1-8.

Sari, R. D. K., Arifin, R., \& Hufron, M. (2020). Pengaruh Persepsi Harga, Kualitas Pelayanan, Lokasi, Brand Image Dan Kualitas Produk Terhadap Keputusan Pembelian Pada Pelanggan Minimarket'(Studi Pada Pelanggan Minimarket Swalayan Sauli Mart Kesamben). Jurnal Ilmiah Riset Manajemen, 9(11), 104-117.

Sitompul, S. S., \& Mastono, M. (2017). ANALISIS PENGARUH PROMOSI, HARGA, DAN KEPERCAYAAN TERHADAP KEPUTUSAN PEMBELIAN ONLINE DI LAZADA. CO. ID PADA MAHASISWA STIE PELITA INDONESIA. Procuratio: Jurnal Ilmiah Manajemen, 5(1), 81-95.

Sumarwan, U. (2011). Perilaku konsumen: Teori dan penerapannya dalam pemasaran. Bogor: Ghalia Indonesia.

Sunardi, A. T. P., \& Suprianto, E. (2020). Pengendalian Kualitas Produk Pada Proses Produksi Rib A320 Di Sheet Metal Forming Shop. Jurnal Industri Elektro Dan Penerbangan, 5(2), 6-15. 
Sunarto, A. (2006). Pengantar Manajemen Pemasaran. Yogyakarta: Yogyakarta, UST Press.

Tjiptono, F., \& Chandra, G. (2016). Service, Quality dan Satisfaction Edisi 4. Yogyakarta: Andi Offset.

Yusup, M. (2011). Analisis pengaruh promosi, harga, kualitas produk dan layanan purna jual terhadap keputusan pembelian sepeda motor honda (studi kasus pada mahasiswa fakultas ekonomi universitas diponegoro semarang). Retrieved from http://eprints.undip.ac.id/29032/1/Skripsi021.pdf. 